\title{
The effect of different depths of medial heel skive on plantar pressures
}

\author{
Daniel R Bonanno ${ }^{1,2^{*}}$, Cheryl Y Zhang ${ }^{1}$, Rose C Farrugia ${ }^{1}$, Matthew G Bull ${ }^{1}$, Anita Raspovic ${ }^{1,2}$, Adam R Bird ${ }^{1,2}$, \\ Karl B Landorf ${ }^{1,2}$
}

From 3rd Congress of the International Foot and Ankle Biomechanics Community

Sydney, Australia. 11-13 April 2012

\section{Background}

Foot orthoses are often used to treat lower limb injuries associated with excessive pronation. There are many orthotic modifications available for this purpose, with one being the medial heel skive. However, empirical evidence for the mechanical effects of the medial heel skive is limited. This study aimed to evaluate the effect that different depths of medial heel skive have on plantar pressures.

\section{Materials and methods}

Thirty healthy adults aged over 18 years with flat feet and no current foot pain or deformity participated in this study. Using the in-shoe Pedar- $\mathrm{X}^{\circledR}$ system, plantar pressure data were collected for the heel, midfoot and forefoot while participants walked along an 8 metre walkway wearing a standardised shoe. Experimental conditions included the following 4 customised orthotic variants: (i) no heel skive, (ii) $2 \mathrm{~mm}$ heel skive, (iii) 4 $\mathrm{mm}$ heel skive and (iv) $6 \mathrm{~mm}$ heel skive.

\section{Results}

Compared to the foot orthoses with no heel skive, statistically significant increases in peak pressure were observed at the medial heel - there was a $15 \%$ increase ( $\mathrm{p}=0.001$ ) with the $4 \mathrm{~mm}$ skive and a $29 \%$ increase ( $\mathrm{p}$ $<0.001$ ) with the $6 \mathrm{~mm}$ skive. No significant change was observed with the $2 \mathrm{~mm}$ heel skive. With respect to the midfoot and forefoot, there were no significant differences between the orthoses.
'Department of Podiatry, Faculty of Health Sciences, La Trobe University, Bundoora, Victoria, 3086, Australia

Full list of author information is available at the end of the article

\section{Conclusions}

The results of this study indicate that a medial heel skive of 4 or $6 \mathrm{~mm}$ can increase peak pressure under the medial heel in asymptomatic flat-footed individuals. Plantar pressures at the midfoot and forefoot were not affected by a medial heel skive of 2, 4 or $6 \mathrm{~mm}$. These findings provide some evidence for the effects of the medial heel skive orthotic modification.

\section{Author details}

'Department of Podiatry, Faculty of Health Sciences, La Trobe University, Bundoora, Victoria, 3086, Australia. ${ }^{2}$ Musculoskeletal Research Centre, Faculty of Health Sciences, La Trobe University, Bundoora, Victoria, 3086, Australia.

Published: 10 April 2012

doi:10.1186/1757-1146-5-S1-09

Cite this article as: Bonanno et al:: The effect of different depths of medial heel skive on plantar pressures. Journal of Foot and Ankle

Research 2012 5(Suppl 1):09.
Submit your next manuscript to BioMed Central and take full advantage of:

- Convenient online submission

- Thorough peer review

- No space constraints or color figure charges

- Immediate publication on acceptance

- Inclusion in PubMed, CAS, Scopus and Google Scholar

- Research which is freely available for redistribution

Submit your manuscript at www.biomedcentral.com/submit
() Biomed Central

\section{() Biomed Central}

